\title{
ROBUST AUTHOR-PUBLISHER RELATIONSHIPS AS PANACEA FOR THE PROBLEMS OF BOOKS PUBLISHING IN NIGERIA
}

\author{
OGUNDEPO A. OLUSOLA \\ Department of General Studies Education, \\ School of General Education, \\ The College of Education, Lanlate, \\ Oyo State, Nigeria. \\ E-mail: solaogundepo@gmail.com (+2348077532416)
}

\begin{abstract}
Books are very essential to the development of any nation. They extend the frontier of knowledge and bring about continuous intellectual development. Hence, the industry that produces books deserves attentions of all stakeholders in nation building. This paper considered the incessant rancor between major stakeholders in the publishing industry as the greatest threat to the growth of the industry and thus recommended a robust author-publisher relationship as the way out. It examined books, publishing, history of publishing in Nigeria and problems of publishing. It explained in clear terms what the specific roles of the publisher and author should be if a successful and mutually beneficial relationship is to be established and maintained. Above all it recommended a symbiotic relationship built on the pillars of mutual understanding and cooperation.
\end{abstract}

Keywords: Books, publishing, author, publisher relationship. 


\section{Introduction}

Books are very essential to the development of any nation. Their impact in literacy development is quite enormous. It is often said that a reading nation is a developed nation. Through books, records, academic information and theories, history, developments and inventions that would have been lost to humanity are kept and preserved. Ojeyinka, Aganbi and Atewolara - Odule (2016) opined that book is seen as a catalyst for mental growth and social integration. They cited Awoniyi (1997) as describing a book as the grand index of technology, government, politics, religion, economy, sociology, medicine, engineering to mention but a few.

As a medium of mass communication, books generally are veritable sources of information to teachers, students, researchers, scholars and general readers. This is perhaps why Kalejaye and Akangbe (2007) described books as indices of progress, pivots as well as springboards of advancement and galvanizers to breakthrough.

The United Nations Education Scientific and Cultural Organization defined a book as a non- periodical printed publication. It has a minimum of 49 pages excluding the cover page. By this definition, a book has the following attributes; it is printed, it is a publication, it has a minimum of 49 pages excluding the cover and it is not a periodical. Morgan (2006) has defined a book as the only place in which you can examine a fragile thought without breaking it or explore an explosive idea without fearing it will go off in your face.

Tomomowo-Ayodele (2018) asserted that book form content and provisions for making and disturbing books varied widely during their long history, but in general, it may be said that a book is designed to serve as an instrument of communication. It is meant to convey a meaning.

One cannot say with exactitude when men began to make books; this is because the books themselves have not survived. However, there are earliest known books in forms of the clay tablets of Mesopotamia and the papyrus rolls of Egypt. Manuscript however began to take on the look of the book around AD 100 when Christians invented the codex (Oyeyinka, Aganbi \& Atewolara-Odule, 2016). The codex was a document in which papyrus pages faced one another and were bound together instead of being rolled up.

Making mass production of printing documents was made possible by the invention of immovable types of printing press by Johannes Guttenberg in 1455. This could be described as the birth of the modern book publishing business (Oso, 2002, Tomomowo-Ayodele, 2018).

\section{What is publishing?}

Publishing as an enterprise involves the processing of an author's ideas generated and written in form of a manuscript into a book for the reading public. This processing involves activities such as selection, preparation and marketing of printed materials. As asserted by The Encyclopedia Britanica (2019), the functions peculiar to the publisher includes selecting, 
editing, and designing the material; arranging its production and distribution and bearing the financial risk or the responsibility of the whole operation. This is perhaps why FEP.FEE.be (2012) described publishing as basically a marketing activity in which finance is the critical tool.

Joseph (2011) opined that
Publishing is a creative process through which different categories of books are published. It is a creative imagination of a number functionaries in the publishing house and those who are fairly distant especially the authors, freelance editors, design compositors, printers, paper and plate merchants, readers and a host of others. Therefore it is appropriate to discuss publishing as a formidable succession of activities no one of which can by itself be called publishing.

In a similar vein, Altbatch and Knight (2007) opined that publishing process coordinates with various processes needed to nurture from an idea in the mind of the author to a printed product available for distribution to the relevant audience. He described it further as the heart of coordination of multimedia of activities to produce a book; that is, dealing with selection, editing of manuscript, planning and supervising the process of transformation of the manuscript into book.

Publishing is the means through which culture, literature scholarship science, technology and professional information are made available to the world. To publish is to make public. Published matters fall into two major classes. These are the periodicals and nonperiodicals. While periodicals are publications that appear at a more or less regular interval and a member of a series, the non-periodicals are those that appear on single occasions. Books arguably constitute the largest class of the non-periodicals and in one form or another they are the oldest of all types of publications.

\section{Books Publishing in Nigeria}

The Presbyterian mission established the first press in Nigeria at Calabar in 1846 with a view to propagating the Christian faith by providing literature to their new believers. This was followed by Henry Townsends in 1959 when he set up another press at Abeokuta. The Abeokuta press eventually produced the first newspaper in Nigeria named Iwe Irohin fun awon ara Egba ati Yoruba (Adelakan, 1995; Ojeyinka, et al., 2016; Tomomowo-Ayodele, 2018).

Tomomowo-Ayodele (2018), citing Aguolu \& Aguolu (2002) reported that the first privately owned newspaper "Anglo African" was issued in 1863 by a Jamaican immigrant named Robert Campbell and that the first Nigeria commercial press The Tika-Tore Printing Works was established in 1910 at Lagos. Though it was not tied to newspaper publishing.

Educational books were imported because the Nigerian school curricular were not 
quite different from her European counterparts. In order to cater for the Nigerian growing educational system, publishing houses began to be set up. This was led by Oxford University Press, who set up a branch of their company in Ibadan in 1949. The Ibadan University Press came on board in 1950. This was followed by Onibonje Press in 1958. There were other initiatives which included African Educational Press, Northern Nigeria Publishing Company, John West Publication, Ilesanmi Press and a host of others.

Apart from Oxford University Press, other British firms also registered their presence in Nigeria controlling the book market in Nigeria before the books indigenization decrees of 1977. These include Longman, Thomas Nelson, Macmillan, Evans and Heinemann (Obiechina, 1973; Aguolu \& Aguolu, 2002). It is pertinent to note that book publishing has continued to enjoy tremendous growth ever since.

\section{Problems of Publishing}

In spite of the noted growth however book publishing in Nigeria is bedeviled with several challenges that portend dangers to the success of the industry. Some of these challenges have been identified by scholars as far back as the 1980s. Unfortunately, rather than abating, the problems are getting worse and threatening the industry (Thomas, 1984; Adesanoye, 1995).

The identified problems include:

(i) Lacks of fund to execute publishing projects which have been found to be capital intensive

(ii) Government attitude towards publishing industry

(iii) The economy

(iv) Poor reading culture

(v) Activities of book pirates

(vi) Infrastructural decay

(vii) Dearth of expertise

(viii) Technology and

(ix) Incessant rancor among major stakeholders.

While all these problems are important and deserve needed attention to enhance real growth in the industry, this paper considers incessant rancor among major stakeholders as a major threat for which solutions should be urgently provided.

The major stakeholders here are the publishers on one hand and the authors on the other hand. The relationship between the authors and publishers are often far from healthy. Lack of mutual understanding leads to jettisoning laudable and viable projects. This does not augur well for the sector to develop. This is so because without an author the publisher has no business and without a publisher the author's ideas remain permanently unknown. A symbiotic relationship is needed to make both parties fruitful. This explains why the concern of this paper is how to solve publishing problems through a robust author-publisher relationship. 


\section{Types of manuscripts}

There are two major types of manuscripts that publishers process into manufactured book. These are the solicited manuscripts and the unsolicited ones. For solicited manuscripts, the publishers own the idea of what he wants to publish. He looks out for established authorities in his area of interests and commissions them to produce a manuscript to his specification. These commissioned authors are usually paid honoraria or royalty. Solicited manuscripts are almost always a group project involving a lead author and other supporting authors.

Unsolicited manuscript on the other hand is a manuscript which an author writes without the publisher's prior invitation, approval or consent. Such manuscripts are sent by the author who hopes that the publisher would find his work publishable and give a publishing contract. Unsolicited manuscripts have a very slim chance of acceptance.

Whether as solicited or unsolicited manuscript, the author-publisher relationship begins when a publisher decides to publish a submitted manuscript. That is the point at which the drawing up of a publishing contract becomes necessary.

The publisher takes all the responsibility for all aspects of the publishing process. When an author has submitted his manuscript, the publisher reviews the work to ensure that it meets the requirements to make it a successful work when it is eventually published. This he does, using a team of editors, proof readers graphic designers and printers. He also makes commercial arrangement wherein he looks for opportunities to get a great number of copies of the book sold. The publisher provides the finance necessary to transform a writer's work into a manufactured book (or digital product). He shoulders the financial risk, manages the risk and turns it into a profit.

Seen as a manufacturer, the major raw material of a publisher is the manuscript produced by a writer. This means then that without the author who produces the manuscript, the publisher has no business. This is why stakeholders have over the years attempted to find a means of engendering successful author-publisher relationships. This has led to researches on author-publisher relationships. These researches, though limited in volume and scope, have tried to examine what the key to successful author-publisher relationships is.

To be able to do justice to a discussion of this subject matter, one needs a clear understanding of the specific roles of the author and the publisher in the publishing business.

\section{Roles of the Author and Publisher}

Palfreyman asserted that the author produces his thoughts and ideas in an original form that will interest, teach, entertain and inspire the world. The publisher on the other hand recognizes this talent and originality, proposes a business deal that will be mutually beneficial to both the author and the publisher, helps the author to make the work the best it can be, presents it in a way people will want to buy and makes sure many people are aware of the work, so that profits will be made from sales of the books. 
She argues further that both the role of the author and publisher are crucial to each other and that neither can succeed without the other. The author creates, the publisher invests and from sales of the work, they create together and from sales of the right to that work, the author earns royalties and fees and the publisher earns his profit. This forms the fulcrum of the author-publisher relationship.

The author-publisher relationship is seen as a service relationship but the relationship poses the big question of who provides service for whom? Authors are often seen as providers of the raw materials needed by publisher. Whereas the publisher offers services to the author to edit, design, print, promote and sell the work of the author on his behalf. This is why Asser (1992), argued that the publisher supplies a service to the author. Both the author and publisher are providing services that are mutually beneficial to both parties.

\section{Keys to a Successful Author-Publisher Relationship}

As can be seen from the discussion so far, the author and publisher are mutually dependent. The publisher depends on authors for manuscripts that can be manufactured into books while the author depends on the publisher for the expertise that turns the manuscript to a worthy book and the financial muscle that ensures the production, promotion and marketing of the book. A successful provision of these services by both parties ensures that the book becomes a success and pays the author's royalties and fees and the publisher's profits.

The success of this relationship rests on how the author and publisher clearly establish the publishing contract and respect the dictates of the document. Book publishing is about rights and obligations of each party. The author has some inalienable rights ensured by copyright laws all over the world. For instance, in Australia, UK, and the US, the author of a work is guaranteed that his or her work is not used without permission from the time of its creation to 70 years after the owner's death.

There are two major kinds of copyright rights. These are the economic rights and moral rights. Before any work is put into any copyright uses, the consent of the author should be sought and received. This is why the publisher has to enter into a contractual agreement with the author to obtain a share in the copyright in order to publish the work.

In the publishing industry, the most important copyright rights are:
i. Publication right,
ii. Reproduction right,
iii. Communication right and,
iv. Translation right.

It is the responsibility of the publisher to draw the publishing contract though it has to be signed by the publisher and the author. As observed by Ihebuzor (2017), no standard publisher and no enlightened author will go ahead with the publishing process of a book without first having the relevant documents signed. 
The contract, in clear terms should contain information covering these broad areas:

$>$ Date of the contract;

$>\quad$ Names of the involved parties;

$>\quad$ The titled of the work;

$>$ Author's warranty (where he confirms that the work is original and he/she controls the right granted, doesn't contain defamatory, libelous and unlawful matters;

$>\quad$ No. of pages;

$>$ Type of production;

$>$ Publication date;

$>$ Delivery date;

$>$ Percentage royalty payment due to author;

$>$ Accounting of sales;

$>$ Revision;

$>$ Termination of contract;

$>$ Arbitration in dispute and options;

$>$ Special provisions, like advance on author's royalties.

$>$ Grant of rights (if any)

$>\quad$ Names and signatures of the parties (A Philips, M.N.K Saunders, S Pundit and D.D Chetty, 2005)

The contract should state in explicit terms whether the publisher is licensing the copyright from the author or buying it outright. The terms of copyright granted and the territories covered by the agreement should also be part of the contract document.

The fees paid/payable to the author should be clearly stated. Is it a once-only fee or an advance fee against royalties according to the sales of the work? Mention should also be made of the installments of payments and accounting periods for calculating the payment. In the same vein, provision must be made for the proportion of sharing subsidiary rights income between the publisher and the author.

In spite of the clear role specifications for publishers and authors and the presence of contractual agreements that should naturally aid a mutually beneficial relationship between both parties, it is often discovered that relationships between authors and publishers are not always the best they could be. A survey in the UK by the Society of Authors reported a range of grievances between authors and publishers. Some of these as listed by Phillips, Saunders, Pundit and Chetty (2005) include poor publicity, lack of continuity in the editorial department, late payment of royalties and advances and lack of communication.

There are often complaints from authors that they are not being treated fairly by publishers. Major complaints include non- payment or late payment of royalties. Some believe that the publishers declare far less than number of copies produced and sold thereby short changing them of the amount of due royalties. 
Publishers too, see such authors as being ingrates. Some erroneously see their acceptance and publication of the work as a favour done to the authors. They wonder why authors do not see the challenges they face in the industry especially by the activities of pirates.

Granted that the cost borne by the publisher is truly enormous and the risk of publishing too is quite high, yet the publisher should try to keep a cordial relationship with his author by being honest. He should ensure that his author gets a regular, honest and clear account of sales made and royalties due to him.

\section{Conclusion}

This paper has examined how a robust author-publisher relationship could solve some of the problems of the publishing industry and enhance its growth. The paper discussed what books are and the emergence of the publishing industry in Nigeria. It also examined problems of book publishing of all the identified problems, the paper focused on incessant rancor between major stakeholders as being the most threatening to the industry and suggested ways of bringing about the needed healthy relationships between publishers and authors.

\section{Recommendations}

In view of the discussion above, it is hereby recommended that:

i. Author should have trusts and confidence in their publishers and desist from the thoughts that every publisher out there is ready to cheat them.

ii. Each party should be aware of his roles and responsibilities and play them well.

iii. Mutual trusts and understanding are needed in a publishing relationship just as in any other.

iv. Publishers should try to keep a cordial relationship with their authors by being honest and fair to them. 


\section{References:}

Adelekan A.I (1995). Hope step flat: A critical survey of the Nigeria publishing industry. Ife: Obafemi Awolowo Alumni lecture series.

Adesanoye F.A (1995). 'Books publishing today in Nigeria: The approach of a bookless society.' In The book in Nigeria: Some current issues Ibadan: Sam Bookman.

Aguolu C.C and Aguolu I.E (2002).'Publishing - structure and development'. In Libraries and information management in Nigeria: Seminal essays on themes and problems.Maiduguri: ED-LINFORM SERVICE.

Altbatch P.G. \& Kmsht J. (2007). The internationalization of higher education: motivations and realities. Journal of studies in international education 11(3).

Asser J.P (1992). Publishing, copyright and the public good. Publishing Research Quarterly $8(2)$.

Awoniyi A. (1997). Publishing in Nigeria in the $21^{\text {st }}$ century: prospect and challenges. Pergamon: Oxford press.

Encyclopedia Britanica

Ihebuzor L. (2017). Principles and practice of book publishing in Nigeria. Lagos: Sibbon Books.

Morgan, P.E (2006) 'Writers' quote'. Retrieved from http//www.writersservice.com/mag/m.quoteswriters-htm on $16^{\text {th }}$ April 2019.

Obiechina E. (1973). An African popular literature: A study of Onitsha market's Pamphlets.

Ojeyinka T.O, Aganbi Y.E \& Atewolara-Odule , O. A. (2016). Problems of book publishing in Nigeria. Journal of Research and Development, 2(10).

Oso L. (2002). Book publishing: A practical guide. Lagos: African Resource Press.

Phillps A, Saunders N.N.K, Pundit S. \& Chatty D.D (2005). The nature of the relationship between authors and publishers. Publishing Research Quarterly, 21(2).

Tomomowo-Ayodele S.O (2018). Impact of indigenous publishing on educational development in nigeria: A case study of selected publishers in Ibadan. Library Philosophy and Practice (e-journal) 1803. 